Click www.researchjournal.co.in/online/subdetail.html to purchase.

International Journal of Commerce and Business Management

Volume 10 | Issue 1 | April, 2017 | 8-14

DOI: 10.15740/HAS/IJCBM/10.1/8-14

$\Rightarrow$ Visit us : www.researchjournal.co.in

RESEARCH PAPER

\title{
Value addition and supply forecast of sapota fruit in India
}

M. K. SHWETHA AND BALACHANDRA K. NAIK

Received : 18.01.2017; Revised : 02.03.2017; Accepted : 16.03.2017

\begin{abstract}
Fruit value chain involves any type of value addition to the horticultural produce which includes processes such as drying, grading, sorting, processing, packaging, advertising, marketing, etc., which adds value and enhance the shelf-life of value added products. The present study was conducted in Northern Karnataka with the objective to analyze the different cost and returns in its value chain management. The primary data related to procurement of raw materials and its rates, inventory management, costs of processing, marketing and its costs and different problems faced during value addition processes were obtained from the value addition units/ processors for the agricultural year 2013-14. The data was analysed using tabular analysis, growth rate analysis, ARIMA model of forecasting and Garrett Ranking Technique. The results were based on primary data collected, with the sample size of eight processing units, twenty wholesaler cum commission agents and twenty retailers for the selected fruit crop. The results revealed that the total cost incurred by the processors in processing of raw sapota into one quintal of fruit was of Rs. 1047. The degree of value addition was found to be 58 per cent. The marketing cost incurred by the retailers in marketing per quintal of sapota fruit was found to be Rs. 110. The supply of sapota in India showed a compound growth rate of 6.15 per cent annually over the period studied. Since the stake holders in value chain of sapota fruit are not integrated, there is a great opportunity to integrate and strengthen the value chain. The processors opined that higher raw materials cost and commission charges, transportation hurdles are the major problems in value addition of sapota. The concerned statutory bodies have to give due attention for providing proper approach roads to the farms, processing units, cold storage, marketing facilities and export opportunities.
\end{abstract}

KEY WORDS : Value chain, Processing, Supply forecast, Raw sapota, Marketing

How to cite this paper : Shwetha, M.K. and Naik, Balachandra, K. (2017). Value addition and supply forecast of sapota fruit in India. Internat. J. Com. \& Bus. Manage, 10(1) : 8-14, DOI: 10.15740/HAS/IJCBM/10.1/8-14.

Correspondence to:

M.K. SHWETHA, Department of Agribusiness Management, College of Agriculture, University of Agricultural Sciences, DHARWAD (KARNATAKA) INDIA

Email: shwethamrutha@gmail.com

Authors' affiliations:

BALACHANDRA K. NAIK, Department of Agribusiness Management, College of Agriculture, University of Agricultural Sciences, DHARWAD (KARNATAKA) INDIA 